\title{
本態性血小板血症の治療
}

桐戸敬太*

\section{Emerging therapeutic strategies for essential thrombocythemia}

\author{
Keita KIRITO
}

要約 : 本態性血小板血症（essential thrombocythemia: ET）の予後を規定する因子は，血栓・出血の合併，骨䯣線 維症や急性骨髄性白血病への移行および他の固形腫瘍の合併であるが, 現時点では, ET を治癒に導く治療は確 立されていないため, 治療の目標は血栓・出血の抑制が主体となる. 血栓・出血のリスクを評価し, それに沿っ て治療の選択がなされる，従来は，年齢と血栓・出血の既往歴のみに基づいてリスク分類が行われてきたが, 最近ではドライバー変異の種類と心臓血管リスク因子の有無なども取り入れられている. さらには，非ドライ バー変異の存在の影響も検討されている。治療手段は, アスピリンを用いた抗血小板療法と細胞減少治療に大 別される，細胞減少治療としては，ハイドロキシカルバミドとアナグレリドがともに第一選択薬として位置付 けられている，新たな治療薬としては，JAK 阻害剤ルキソリチニブおよびインターフェロン等があり臨床試験 が進んでいる。

Key words: essential thrombocythemia, aspirin, hydroxycarbamide, anagrelide gene mutation

\section{1.はじめに}

本態性血小板血症（essential thrombocythemia: ET） は骨髄増殖性腫瘍 (myeloproliferative neoplasms: MPN）に分類される疾患であり, ドライバー変異の 存在と血小板を中心とした骨髄系細胞の増加を特徴 とする ${ }^{1 ）}$. ドライバー変異としては, JAK2V617F, Calreticulin exon9 変異および MPL変異が知られてお り，国内外の報告でもその出現頻度は 40〜 $50 \%, 20$ 〜30\%および 10\%程度とされる. ET の生命予後は, 健常人と比べると著しく劣ることはないとされる。 一方, 血栓・出血の合併率は高く, 発症・診断時に すでに $20 \%$ 程度の頻度で合併している. その後の経 過中にも, 約 20〜30\%の症例で血栓・出血の併発が みられる ${ }^{1)}$.このため, 現時点においても ETの治療 は血栓・出血の合併の抑制することが中心となって いる. 一方, ETでは様々な全身的な症状を伴うこと

*責任者連絡先：

山梨大学医学部血液 ・腫瘍内科

干 409-3898 山梨県中央市下河東 1110

Tel: 055-273-9432, Fax: 055-273-1274

E-mail: kirito@yamanashi.ac.jp
も多く, 生活の質や社会的活動に影響を認めること もある2).

\section{ETにおける血栓傾向の病態生理}

ET を含むMPN において，血栓合併の病態につい ては, 血小板や赤血球のみならず好中球, 単球およ び血管内皮細胞などが関与していることが明らかに なりつつある ${ }^{3,4)}$. JAK2V617F を発現している好中 球や血管内皮細胞では P セレクチンやインテグリン などの接着分子の発現が増加していることが確認さ れている。 また, MPN症例では炎症性サイトカイン の産生上昇, また好中球から放出され血栓傾向に関 わるとされる NETs (neutrophil extracellular traps) レ ベルが高いことが確認されている，さらに，MPN症 例では，血管攣縮による冠動脈疾患の合併が高く， これには赤血球から放出される細胞外小胞の一種で ある microvesicle が関与している。 
表 1 ET の生命予後評価（IPSET と MIPSS-ET）

\begin{tabular}{|c|c|c|c|c|}
\hline \multicolumn{5}{|c|}{ A スコアの実際 } \\
\hline & & & IPSET & MIPSS-ET \\
\hline \multicolumn{3}{|l|}{ リスク因子 } & \multicolumn{2}{|c|}{ スコア } \\
\hline \multirow{2}{*}{ 年齢 } & & 60 歳以上 & 2 & 4 \\
\hline & & 60 歳未満 & 0 & 0 \\
\hline \multirow{2}{*}{\multicolumn{2}{|c|}{ 白血球数 }} & $11,000 / \mu \mathrm{L}$ 以上 & 1 & 1 \\
\hline & & $11,000 / \mu \mathrm{L}$ 未満 & 0 & 0 \\
\hline \multirow{2}{*}{\multicolumn{2}{|c|}{ 血栓症既往 }} & あり & 1 & - \\
\hline & & なし & 0 & - \\
\hline \multirow{2}{*}{\multicolumn{2}{|c|}{ 性別 }} & 男性 & - & 1 \\
\hline & & 女性 & - & 0 \\
\hline \multirow{2}{*}{\multicolumn{2}{|c|}{ 高リスク遺伝子変異* }} & あり & - & 2 \\
\hline & & なし & - & 0 \\
\hline \multicolumn{5}{|c|}{ B スコアに基づいた予後評価 } \\
\hline & スコア & リスク分類 & \multicolumn{2}{|c|}{ 生存期間中央値 } \\
\hline \multirow{3}{*}{ IPSET } & 0 & 低リスク & \multicolumn{2}{|c|}{ 到達せず } \\
\hline & $1 \sim 2$ & 中間リスク & \multicolumn{2}{|c|}{24.5 年 } \\
\hline & $3 \sim 4$ & 高リスク & \multicolumn{2}{|c|}{14.7 年 } \\
\hline \multirow{3}{*}{ MIPSS-ET } & $0 \sim 1$ & 低リスク & \multicolumn{2}{|c|}{34.4 年 } \\
\hline & $2 \sim 5$ & 中間リスク & \multicolumn{2}{|c|}{14.1 年 } \\
\hline & $6>$ & 高リスク & \multicolumn{2}{|c|}{7.9 年 } \\
\hline
\end{tabular}

*高リスク遺伝子変異 : SRSF2, SF3B1, U2AFI もしくはTP53の 変異

\section{ETの予後とリスク評価}

\section{1）生命予後のリスク評価}

$\mathrm{ET}$ 症例の生命予後は, 一般的に同年齢の健常人と 異ならないと考えられている，生命予後に関連する 因子としては, 白血球数増加, 血栓の既往および年 齢が抽出されており，これをもとにした生命予後予 測スコアがIPSET（international prognostic score for ET）として発表されている ${ }^{5)}$. その後, ETにおいて も多くの遺伝子変異の関与が明らかとなり, 予後と の関連性についても解析が進められた ${ }^{6)}$. これらの 遺伝子変異情報をも組み込んだ ET の予後予測シス テムとして Mayo Clinic の Tefferi らは MIPSS-ET (mutation-enhanced international prognostic system) を 発表している7). このシステムでは予後不良遺伝子 変異 $(S R S F 2, S F 3 B 1, U 2 A F 1$ もしくはTP53) が存
表 2 IPSET-T に基づいた血栓リスク評価

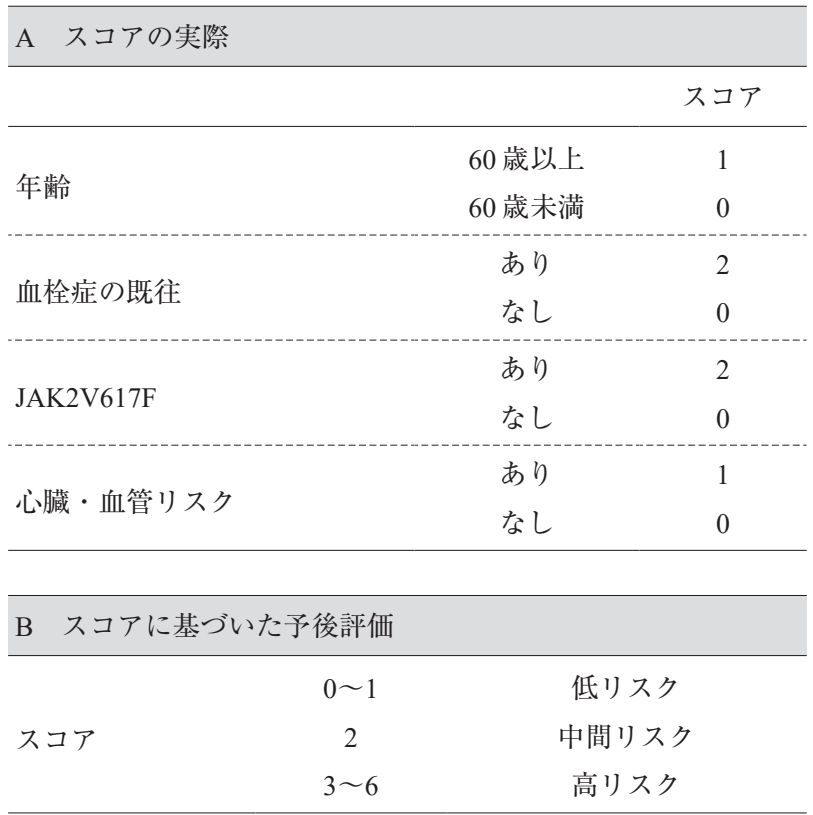

在する場合 2 点, 60 歳以上を 4 点, 男性である場合 を 1 点そして白血球数が $11,000 / \mu \mathrm{L}$ を 1 点として, 低 リスク $(0,1$ 点), 中間リスク $(2 \sim 5$ 点 $)$ および高 リスク（6点以上）に層別化している7)。それぞれ の群の生存期間中央值は, 34.4 年, 14.1 年および 7.9 年であった．表 1 にIPSET およびMIPSS-ETを示す。

\section{2）血栓・出血のリスク評価}

ET における血栓・出血発症のリスク因子として は, 年齢 (60 歳以上) と血栓・出血の既往とするこ とが一般的であった ${ }^{8)}$. これらの因子に加えて, $J A K 2 \mathrm{~V} 617 \mathrm{~F}$ 変異の存在, 糖尿病, 高血圧症, 脂質異 常症および喫煙などの心臓血管リスクの存在を加え た新たなリスク分類として, IPSET-Tおよび RevisedIPSET-T が提唱されている9 10). NCCN ガイドライ ンをはじめ, 最近の海外のガイドラインでは IPSETT もしくは R-IPSET-T が採用されている。表 2 およ び表 3 にIPSET-T およびR-IPSET-Tを示す. 白血球 数の増加が血栓リスクとなるかについては, さまざ まな議論がある. 最近のメタアナリシスでは, 白血 球数の上昇（正常值以上）はETに打ける動脈血栓 リスクと関連（relative risk 1.65）することが示され ている ${ }^{11)}$. 血小板数の増加は, 出血リスクと関連し ている ${ }^{12)}$. 
表 3 R-IPSET-T に基づいた血栓リスク評価

\begin{tabular}{|c|c|c|c|c|c|}
\hline & $\begin{array}{c}\text { 超低 } \\
\text { リスク }\end{array}$ & $\begin{array}{c}\text { 低 } \\
\text { リスク }\end{array}$ & $\begin{array}{c}\text { 中間 } \\
\text { リスク }\end{array}$ & $\begin{array}{l}\text { 高 } \\
\text { リスク }\end{array}$ & $\begin{array}{c}\text { 高 } \\
\text { リスク }\end{array}$ \\
\hline 年齢 & $\begin{array}{l}60 \text { 歳 } \\
\text { 未満 }\end{array}$ & $\begin{array}{l}60 \text { 歳 } \\
\text { 未満 }\end{array}$ & $\begin{array}{l}60 \text { 歳 } \\
\text { 以上 }\end{array}$ & $\begin{array}{l}60 \text { 歳 } \\
\text { 以上 }\end{array}$ & 問わず \\
\hline $\begin{array}{l}\text { 血栓症既往 } \\
\text { JAK2V617F 変異 }\end{array}$ & $\begin{array}{l}\text { なし } \\
\text { なし }\end{array}$ & $\begin{array}{l}\text { なし } \\
\text { あり }\end{array}$ & $\begin{array}{l}\text { なし } \\
\text { なし }\end{array}$ & $\begin{array}{l}\text { なし } \\
\text { あり }\end{array}$ & $\begin{array}{c}\text { あり } \\
\text { 問わず }\end{array}$ \\
\hline
\end{tabular}

表 4 血栓リスクに基づいたET 治療

\begin{tabular}{lcccc}
\hline & 超低リスク & 低リスク & 中間リスク & 高リスク \\
\hline アスピリン & なし & 適応 & 適応 & 適応 \\
細胞減少療法 & なし & なし & 適応 & 適応 \\
\hline
\end{tabular}

\section{ET 治療の実際}

ET 治療の目的は, 血栓・出血の抑制である. 国内 での治療の概略を表 4 に示す。以下には，それぞれ の治療方法について, その根拠となったエビデンス について示す。

\section{1）抗血小板薬}

ETに対する抗血小板剂として, 一般的には低用量 アスピリンを用いることが推奨されている ${ }^{8)}$. しか しながら, PVとは異なり ETにおけるアスピリンの 血栓抑制効果については，前向きに臨床試験では検 証がなされていない. 低リスク ET症例を対象とし た後ろ向き解析研究では, 未治療群とアスピリンを 中心とした抗血小板療法を受けた群では, 血栓イベ ントの発症率には相違を認めない結果であった ${ }^{13)}$. ただし，JAK2V617F 陽性群に限ると抗血小板療法群 では静脈血栓の発症が低く，また心血管リスクを要 する群についての解析では, 抗血小板療法群で動脈 血栓が低かった ${ }^{13)}$ 。さらに, 低リスク ET症例につ いてドライバー変異に基づいて, 抗血小板療法と無 治療観察とを比較した解析が行われている ${ }^{14)}$.この 解析では, CALR変異陽性例については, 低用量ア スピリンにより血栓イベントの発症率は抑制されず, 逆に出血の合併症率が増加することが確認されてい る ${ }^{14)}$ 。なお, ETにおける抗血小板療法に関しての メタアナリシスも行われているが, 明らかな血栓抑 制効果は確認されなかったと結論づけられている ${ }^{15)}$. 最近，アスピリンの投与方法の違いにより, ET 症例
における血小板機能の抑制効果に相違がみられるか についての研究結果が発表されている ${ }^{16)}$. COX1 阻 害を指標とした解析により，1日1回投与と比較し 1 日に 2 ないし 3 回投与することで有意に血小板機能 が抑制されるとしている ${ }^{16)}$.

\section{2）細胞減少療法}

\section{(1) ハイドロキシウレア}

(1)ハイドロキシウレアのエビデンスと位置づけ ET に扔ける細胞減少治療においてハイドロキシウレア （hydroxyurea: HU）は, 長らく中心的な役割を果た している. HUが ETに対して, 血栓の合併を抑制 していることは, 1995 年に発表された前向き試験に おいて確認されている ${ }^{17)}$. さらに, アナグレリドを 対照とした2つのランダム化比較試験が行われて おり ${ }^{18,19)}$ ，血栓イベントの抑制について HUはアナ

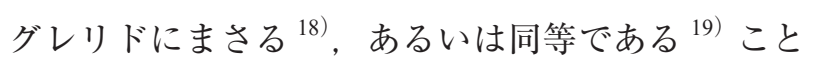
が確認されている。これらの臨床試験は, 高リスク 症例を対象としているが, 最近 40〜 59歳でかつ他の リスク因子（血栓既往, 高血圧症や糖尿病などの心 血管リスク因子および 150 万/ $\mu \mathrm{L}$ 以上の血小板増加） のない群を対象として, HU+アスピリンとアスピリ ン単独での 2 群の前向き比較試験の結果が発表さ れた ${ }^{20)}$. プライマリーエンドポイントは, 動脈・静 脈血栓の発症, 重篤な出血の合併および心血管合併 症のいずれかまでの期間とされた。両グループでの 相違は認められなかった。 また, 生存や骨髄線維症・ AMLへの移行についても両群では差がない結果で あった。これより,この年齢の群でかつ他のリスク 因子のない場合には, HUの使用は推奨されないと 結論づけられている ${ }^{20)}$. 一方, 米国の SEER デー夕 ベースをもとにした後ろ向きコホート研究により, 66 歳以上の ET 症例では, HU の使用と血栓イベント の低下また生存率の改善との関連が確認されてい $ろ^{21)}$.

(2)ハイドロキシウレアの有害事象 HUに関連する 有害事象としては, 皮膚・粘膜障害や発熱などがあ る. HUで治療を行った MPN 症例 3,411 例について の解析では, 約 5\%でこれらの有害事象が認められ ている22)。また, PVおよびETにおける HUの使用 は非黒色腫皮膚癌の発症リスクとなることも指摘さ れている ${ }^{23)}$. 国内からの報告例は少ないが, 我々は 
最近 HUでの治療中に頭皮に扁平上皮癌を発症した PV 症例を経験している ${ }^{24)}$. 日本人症例においても, 皮膚癌の発症は注意すべき HU の有害事象と考えら れる. HUが骨髄線維症や AML の病型移行を促す可 能性については, 多くの議論がなされている. Blast phase MPN 症例のうち, HUの治療歴を有する場合 にはTP53 変異を伴う例が多いことが報告されてい ることなどより, HUの使用がMPNにおける病型移 行のリスクとなるのではないかとも想定された。し かしながら, その後の観察研究においては, HU と 病型移行との関連性は明らかになっていない25).

(2) アナグレリド

(1)アナグレリドのエビデンスと位置づけ アナグレ

リドは, 当初 phosphodiestrase III 阻害剂として開発 されたが, 血小板減少作用を有することが明らかに なり, ヨーロッパでは 1990 年代より ET の治療薬と して用いられてきた。 その後, HUを対象としたラ ンダム化試験によりその血栓・出血の抑制効果につ いて検証を受けている ${ }^{18,19)}$. 国内に拈いても, 高リ スク ET 症例を対象とした PhaseIII 試験が行われ, 血 小板減少効果と安全性について評価された ${ }^{26,27)}$ 。こ れらの臨床試験の結果をもって, 国内のガイドライ ンにおいてはアナグレリドは, 高リスク ET症例の 細胞減少治療の第一選択薬として位置付けられて いる ${ }^{8)}$.さらに, 国内からは観察研究として高リス ク ET 症例に対するアナグレリドの血小板減少効果 についての発表がなされている ${ }^{28,29) .}$

(2)アナグレリドの有害事象 アナグレリドの有害事 象としては, 国内臨床試験などでも頭痛や動悸が比 較的高頻度に確認されている。 アナグレリドが心機 能を低下させるかについては, HUを対象に左室駆 出率を指標としてランダム化比較試験で検証が行わ れている ${ }^{30)}$. その結果, 左室駆出率の変化は両群で 相違がないことが確認された ${ }^{30)}$. 一方, アナグレリ ドの投与と腎障害との関連性が指摘されており ${ }^{31)}$, 今後の展開には注意する必要がある。ヨーロッパで の大規模な解析では, アナグレリドとアスピリンの 併用により, 出血リスクが増加するとの指摘もなさ れている32).

\section{5. 妊孕可能年代での ET 症例への対応}

ET は, 妊孕性のある年代の女性にも比較的多く発 症する。このような年代の ET 症例では, 妊娠前お よび妊娠・出産に関する課題にも対応する必要があ る.一般的に, ET 症例においては正常出産にいたる 比率が低いことが指摘されている. 2018 年に発表さ れた Greisshammer らの文献をもとにした解析では， 正常出産率は $68.5 \%$ であった ${ }^{33)}$. また, 母体の合併 症として重篤な血栓が $1.8 \%$, 出血が $2.4 \%$ に確認さ れている ${ }^{33)}$.イギリスにおける前向きコホート研究 では, 2010 年から 2012 年に MPNを伴う妊娠例が 58 例あり，うち 47 例は $\mathrm{ET}$ 合併例であった ${ }^{34)}$ 。この報 告では，流産率は $1.7 \%$ であった。一方，9\%に子凋 前症の合併が見られている ${ }^{34)}$. 最近発表されたメ夕 アナリシスでは, 1,210 例の MPN 症例の妊娠のう ち, $71.3 \%$ が正常出産であった ${ }^{35)}$. ET 症例に挙児希 望がある場合には，あらかじめこのようなリスクが あることを，血液内科医のみならず産科医も交えて 十分に話し合っておく必要がある.

$\mathrm{ET}$ 症例が妊娠した場合の対応については, 症例数 も少なく明確なエビデンスに基づいた治療指針は構 築されていない. 海外のガイダンスではアスピリン や低分子量へパリンを用いた血栓予防が推奨されて いる ${ }^{36)}$. また, 以前の妊娠時に正常出産にいたらな かったり血栓・出血の合併を認めた場合, あるいは 血小板数が著明に増加している場合には, 細胞減少 治療の併用を検討する。細胞減少治療としては, HU は催奇形性の問題, アナグレリドは胎盤を通過し胎 児の血小板減少を誘発するなどの懸念があり一般的 には禁忌である ${ }^{36)}$. 一方, インターフェロンについ ては, その併用により正常出産に至った症例が国内 外より報告されている ${ }^{37)}$. 特に PEG 化製郕の併用が 望ましいとの意見がある ${ }^{36)}$ 。ただし，国内に扔いて は, ETに対するインターフェロン治療は適応外使用 であることは, 留意しておく必要がある。アスピリ ンとインターフェロンの使用については, 正常出産 のオッズ比上昇と関連することが, 最近発表された メタアナリシスで報告されている ${ }^{35)}$. 


\section{6. 開発中・臨床試験中の薬剤}

ETに対する新たな治療薬の開発も進められてい る. 以下に代表的な薬剤について示す.

1）ルキソリチニブ

JAK1/JAK2 阻害剂ルキソリチニブは，国内外で骨 髄線維症および真性多血症の治療薬として承認を受 けている，骨髄線維症に対しては，脾腫の軽減およ び全身症候の改善効果が確認されている，真性多血 症においては, HU不応・不耐容症例に対して,へ マトクリット值低下を含めた血液所見の改善, 脾腫 軽減さらに全身症候の改善効果が認められる. ET を 対象としたルキソリチニブの臨床試験についても, $\mathrm{HU}$ 不応・不耐容例を対象として行われている。ル キソリチニブの投与量ごとに比較を行った Phase2 試 験では, $25 \mathrm{mg}$ の 1 日 2 回投与群および $50 \mathrm{mg} 1$ 回投 与群血小板数の低下効果および全身症状の改善が得 られることが確認された ${ }^{38)}$ ，一方，同様に HU 不 応・不耐容の $\mathrm{ET}$ 症例について，ルキソリチニブと best available therapy（BAT）にランダムに振り分け られた Phase2 試験（MAJIC-ET 試験）では，1 年時 点での両群における complete response（血小板数< 40 万 $/ \mu \mathrm{L}$ ，白血球数 1 万 $/ \mu \mathrm{L}$ および脾腫を認めず）に 有意差は確認できなかった ${ }^{39)}$ ．また，血栓・出血お よび病型移行についても両群で差は見られなかっ た ${ }^{39)}$. MAJIC-ET 試験症例を対象して，ドライバー 変異および非ドライバー変異の存在が治療反応に及 ぼす影響についても解析が行われている ${ }^{40)}$ 。 ドライ バー変異の影響については，JAK2V617F 変異陽性例 では他の変異例と比較し，血小板減少効果が得られ やすい傾向にあった。ルキソリチニブ中断に至る理 由として，JAK2 $\mathrm{V} 617 \mathrm{~F}$ 陽性症例では病型移行が多 かったが，非 JAK2V617F 陽性では治療不応が多かっ た。非ドライバー変異は，ベースラインにおいて約 $30 \%$ 症例で認められており, TET2 変異, TP53 変 異および SF3B1 変異の順に頻度が高い結果であっ た. TP53 変異および SF3B1 変異の存在は, 病型移行 との関連性が確認された。ルキソリチニブの使用は これらの変異による病型進行の抑制への関与は確認 できなかった ${ }^{40)}$.
2）インターフェロン

ETを対象としたインターフェロン（interferon: IFN）の臨床試験は，古くは 1980 年代まで遡る ${ }^{41)}$. 当初は, その有害事象のために高い中断率が課題で あった． 2000 年代以後に，ポリエチレングリコール （PEG）を結合させた製片が開発され，ETを含む MPN に対する臨床試験が行われている。 QunitasCardama らは 40 例の PV および 39 例の ET 症例に対 して PEG-IFN- $\alpha-2 \mathrm{a}$ を用いた臨床試験を行ってい る ${ }^{42)}$ 。観察期間中央值は 21 ケ月であり， $\mathrm{ET}$ 症例の うち $76 \%$ において血小板数が 40 万 $/ \mu \mathrm{L}$ かつ血栓症の 合併なしと定義された complete hematologic response （CHR）が得られている。JAK2V617F 変異陽性につ いては allele burden ( $\mathrm{AB})$ 值の変化も経時的に解析 がなされており， ET症例では 1 例で JAK2 V617F AB の完全な消失が確認されている ${ }^{42)}$ ，この集団につい ては，さらに観察期間中央值 42 ヶ月後 ${ }^{43}$ おおよび 83 ケ月後 ${ }^{44)}$ の follow-up 解析が行われている. 83 ケ 月解析時点までの脱落者は 18 例 (22\%) であった. HU に不応・不耐容の高リスク ET（65 例）および PV (50 例) 症例を対象とした, PEG-IFN- $22 \mathrm{a}$ の Phase2 試験も行われている ${ }^{45)}$. プライマリーエンドポイン トは, ELN（European Leukemia Net）基準での完全 寞解 (complete response: CR) および部分寛解 (partial response: PR）の到達率とされた。 ET 症例では $22 \%$ が $\mathrm{CR}, 38 \%$ が PRに到達しており，CALR 遺伝子変 異陽性例の方が $\mathrm{CR}$ 達成率が高い結果であった ${ }^{45)}$. イギリスからは，臨床試験外で様々な理由により IFNで治療を受けた ET 症例の治療成績についても報 告されている ${ }^{46)}$. 53 例が解析対象であり，うち 40 例で CHRが達成されている. 追跡期間中央值は 9 年 であり，治療中断に至った例は 6 例（11\%）のみで あった。また，骨髄線維症およびAMLへの移行例 は認められなかった ${ }^{46)}$. 国内においては, IFNは未 承認であるが妊娠例などを中心に使用例の報告がな されている ${ }^{37)}$ 。新たな IFN としては, Ro-PEG-IFNa $2 \mathrm{~b}$ が注目されている。これまでにPVを対象とした 臨床試験の結果が報告されている. HU をコントロー ル群としたランダム化 Phase3 試験（PROUD-PV 試 験）では, 血液学的効果・脾臓縮小効果について $\mathrm{HU}$ 対する Ro-PEG-INF- $\alpha 2 b$ の非劣勢が証明されてい 
る ${ }^{47)}$.さらに, この試験の登録症例については, 延 長試験（CONTINUATION-PV 試験）に進み引き続き 解析が行われている. Ro-PEG-INF- $\alpha 2 \mathrm{~b}$ 群では CHR 到達例の比率がその後も増加したのに対して, HU 群 では低下したことから 36 ケ月時点での解析では RoPEG-INF- $\alpha 2 b$ 群の方が勝る結果となった ${ }^{47)}$. また, JAK2V617F AB についても Ro-PEG-INF- $\alpha 2$ b 群では 低下傾向を維持していた. 現在, ETについてもアナ グレリドを対象とした Ro-PEG-INF- $\alpha 2 b$ のランダム 化試験（ClinicalTrials.gov Identifier: NCT04285086) が行われており, 国内からもいくつかの施設が参加 している。

\section{3）その他}

TP53 制御に関わる分子である MDM2 をターゲッ トとした Idasanultin, Lysine-specific demethylase1 （LSD1）阻害剂であるIMG7289（bomedemstat）など が開発中であり，臨床試験が進められている ${ }^{48)}$.

\section{7. 結論}

ET 治療において, 血栓リスクのコントールについ ては前向き臨床試験も行われ，エビデンスが確立さ れつつある. 一方, ET の病的クローンを根絶を目指 し, 病型移行の抑制ひいては治癒を目標とした治療 法の開発はまだ発展途上である.今後は, 血栓・出 血イベントの抑制のみならずETの治癒を目指した 治療の確立が必要であると考えられる。

\section{著者の利益相反（COI）の開示：}

講演料・原稿料など（ノバルティスファーマ株式会 社, 武田薬品工業)

\section{文献}

1) Tefferi A, Pardanani A: Essential Thrombocythemia. N Engl J Med. 381: 2135-2144, 2019.

2) Harrison CN, Koschmieder S, Foltz L, et al.: The impact of myeloproliferative neoplasms (MPNs) on patient quality of life and productivity: Results from the international MPN Landmark survey. Ann Hematol 96: 1653-1665, 2017.

3) Hasselbalch HC, Elvers M, Schafer AI: The pathobiology of thrombosis, microvascular disease, and hemorrhage in the myeloproliferative neoplasms. Blood 137: 2152-2160, 2021.

4) Guy A, Poisson J, James C: Pathogenesis of cardiovascular events in BCR-ABL1-negative myeloproliferative neoplasms. Leukemia 35: 935-955, 2021.
5) Passamonti F, Thiele J, Girodon F, et al.: A prognostic model to predict survival in 867 World Health Organization-defined essential thrombocythemia at diagnosis: A study by the International Working Group on Myelofibrosis Research and Treatment. Blood 120: 1197-1201, 2012.

6) Tefferi A, Lasho TL, Guglielmelli P, et al.: Targeted deep sequencing in polycythemia vera and essential thrombocythemia. Blood Adv 1: 21-30, 2016.

7) Tefferi A, Guglielmelli P, Lasho TL, et al.: Mutationenhanced international prognostic systems for essential thrombocythaemia and polycythaemia vera. Br J Haematol 189: 291-302, 2020.

8) Shimoda K, Takahashi N, Kirito K, et al.: JSH Practical Guidelines for Hematological Malignancies, 2018: I. Leukemia-4. Chronic myeloid leukemia (CML)/ myeloproliferative neoplasms (MPN). Int $\mathrm{J}$ Hematol 112: 268-291, 2020.

9) Barbui T, Finazzi G, Carobbio A, et al.: Development and validation of an International Prognostic Score of thrombosis in World Health Organization-essential thrombocythemia (IPSET-thrombosis). Blood 120: 5128-5133, 2012.

10) Barbui T, Vannucchi AM, Buxhofer-Ausch V, et al.: Practicerelevant revision of IPSET-thrombosis based on 1019 patients with WHO-defined essential thrombocythemia. Blood Cancer J 5: e369, 2015.

11) Carobbio A, Ferrari A, Masciulli A, et al.: Leukocytosis and thrombosis in essential thrombocythemia and polycythemia vera: A systematic review and meta-analysis. Blood Adv 3: 1729-1737, 2019.

12) Guglielmelli $P$, Gangat $N$, Coltro G, et al.: Mutations and thrombosis in essential thrombocythemia. Blood Cancer J 11: 77, 2021.

13) Alvarez-Larrán A, Cervantes F, Pereira A, et al.: Observation versus antiplatelet therapy as primary prophylaxis for thrombosis in low-risk essential thrombocythemia. Blood 116: 1205-1210, 2010.

14) Alvarez-Larrán A, Pereira A, Guglielmelli $P$, et al.: Antiplatelet therapy versus observation in low-risk essential thrombocythemia with CALR mutation. Haematologica 2016.

15) Chu DK, Hillis CM, Leong DP, et al.: Benefits and risks of antithrombotic therapy in essential thrombocythemia: A systematic review. Ann Intern Med 167: 170-180, 2017.

16) Rocca B, Tosetto A, Betti S, et al.: A randomized doubleblind trial of 3 aspirin regimens to optimize antiplatelet therapy in essential thrombocythemia. Blood 136: 171-182, 2020.

17) Cortelazzo S, Finazzi G, Ruggeri M, et al.: Hydroxyurea for patients with essential thrombocythemia and a high risk of thrombosis. N Engl J Med 332: 1132-1136, 1995.

18) Harrison CN, Campbell PJ, Buck G, et al.: Hydroxyurea compared with anagrelide in high-risk essential thrombocythemia. N Engl J Med 353: 33-45, 2005.

19) Gisslinger H, Gotic $M$, Holowiecki J, et al.: Anagrelide compared with hydroxyurea in WHO-classified essential thrombocythemia: The ANAHYDRET Study, a randomized controlled trial. Blood 121: 1720-1728, 2013.

20) Godfrey AL, Campbell PJ, MacLean C, et al.: Hydroxycarbamide plus aspirin versus aspirin alone in patients with essential thrombocythemia age 40 to 59 years without high-risk features. J Clin Oncol 36: 3361-3369, 2018. 
21) Podoltsev NA, Zhu M, Zeidan AM, et al.: Impact of hydroxyurea on survival and risk of thrombosis among older patients with essential thrombocythemia. J Natl Compr Canc Netw 17: 211-219, 2019.

22) Antonioli E, Guglielmelli P, Pieri L, et al.: Hydroxyurearelated toxicity in 3,411 patients with Ph'-negative MPN. Am J Hematol 87: 552-554, 2012.

23) Gómez M, Guillem V, Pereira A, et al.: Risk factors for nonmelanoma skin cancer in patients with essential thrombocythemia and polycythemia vera. Eur J Haematol 96: 285-290, 2016.

24）鈴木愛，前島え，大沼毅，他：Hydroxycarbamideによる 細胞減少療法中に頭部扁平上皮がんを発症した真性赤血 球増加症. 臨床血液 61: 1670-1672, 2020.

25) Cuthbert D, Stein BL: Therapy-associated leukemic transformation in myeloproliferative neoplasms-What do we know? Best Pract Res Clin Haematol 32: 65-73, 2019.

26) Kanakura Y, Miyakawa Y, Wilde P, et al.: Phase III, singlearm study investigating the efficacy, safety, and tolerability of anagrelide as a second-line treatment in high-risk Japanese patients with essential thrombocythemia. Int J Hematol 100: 353-360, 2014.

27) Kanakura Y, Shirasugi Y, Yamaguchi $H$, et al.: A phase 3b, multicenter, open-label extension study of the long-term safety of anagrelide in Japanese adults with essential thrombocythemia. Int J Hematol 108: 491-498, 2018.

28) Ito T, Hashimoto $Y$, Tanaka $Y$, et al.: Efficacy and safety of anagrelide as a first-line drug in cytoreductive treatment-naïve essential thrombocythemia patients in a real-world setting. Eur J Haematol 103: 116-123, 2019.

29) Hashimoto $Y$, Ito T, Tanaka $Y$, et al.: Comparison of starting doses of anagrelide as a first-line therapy in patients with cytoreductive therapy-naïve essential thrombocythemia: Difference between starting at 0.5 and $1.0 \mathrm{mg} /$ day. Int J Hematol 112: 33-40, 2020.

30) Gotic M, Egyed M, Gercheva L, et al.: Cardiovascular safety of anagrelide hydrochloride versus hydroxyurea in essential thrombocythaemia. Cardiovasc Toxicol 21: 236-247, 2021.

31) Kwiatkowski J, Kuliszkiewicz-Janus M, Rymer W, et al.: Treatment of essential thrombocythemia with anagrelide is associated with an increased risk of worsened kidney function. Pharmacology 2021.

32) Birgegård G, Besses $C$, Griesshammer $M$, et al.: Treatment of essential thrombocythemia in Europe: A prospective longterm observational study of 3649 high-risk patients in the Evaluation of Anagrelide Efficacy and Long-term Safety study. Haematologica 103: 51-60, 2018.

33) Griesshammer M, Sadjadian P, Wille K: Contemporary management of patients with BCR-ABL1-negative myeloproliferative neoplasms during pregnancy. Expert Rev Hematol 11: 697-706, 2018.

34) Alimam S, Bewley S, Chappell LC, et al.: Pregnancy outcomes in myeloproliferative neoplasms: UK prospective cohort study. Br J Haematol 175: 31-36, 2016.
35) Maze D, Kazi S, Gupta V, et al.: Association of treatments for myeloproliferative neoplasms during pregnancy with birth rates and maternal outcomes: A systematic review and metaanalysis. JAMA Network Open 2: e1912666-e, 2019.

36) Robinson SE, Harrison CN: How we manage Philadelphianegative myeloproliferative neoplasms in pregnancy. $\mathrm{Br} \mathrm{J}$ Haematol 189: 625-634, 2020.

37) Edahiro $Y$, Yasuda $H$, Gotoh $A$, et al.: Interferon therapy for pregnant patients with essential thrombocythemia in Japan. Int J Hematol 113: 106-111, 2021.

38) Verstovsek S, Passamonti F, Rambaldi A, et al.: Ruxolitinib for essential thrombocythemia refractory to or intolerant of hydroxyurea: Long-term phase 2 study results. Blood 130: 1768-1771, 2017.

39) Harrison CN, Mead AJ, Panchal A, et al.: Ruxolitinib vs best available therapy for ET intolerant or resistant to hydroxycarbamide. Blood 130: 1889-1897, 2017.

40) O'Sullivan JM, Hamblin A, Yap C, et al.: The poor outcome in high molecular risk, hydroxycarbamide-resistant/intolerant ET is not ameliorated by ruxolitinib. Blood 134: 2107-2111, 2019.

41) Velu T, Delwiche F, Gangji D, et al.: Therapeutic effect of human recombinant interferon-alpha-2C in essential thrombocythaemia. Oncology 42 Suppl 1: 10-14, 1985.

42) Quintás-Cardama A, Kantarjian H, Manshouri $T$, et al.: Pegylated interferon alfa-2a yields high rates of hematologic and molecular response in patients with advanced essential thrombocythemia and polycythemia vera. J Clin Oncol 27: 5418-5424, 2009.

43) Quintás-Cardama A, Abdel-Wahab O, Manshouri T, et al.: Molecular analysis of patients with polycythemia vera or essential thrombocythemia receiving pegylated interferon

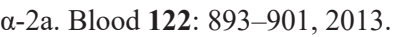

44) Masarova L, Patel KP, Newberry KJ, et al.: Pegylated interferon alfa-2a in patients with essential thrombocythaemia or polycythaemia vera: A post-hoc, median 83 month followup of an open-label, phase 2 trial. Lancet Haematol 4: e165e75, 2017.

45) Yacoub A, Mascarenhas J, Kosiorek H, et al.: Pegylated interferon alfa-2a for polycythemia vera or essential thrombocythemia resistant or intolerant to hydroxyurea. Blood 134: 1498-1509, 2019.

46) Desterro J, McLornan DP, Curto Garcia N, et al.: Essential thrombocythaemia treated with recombinant interferon: 'real world' United Kingdom referral centre experience. Br J Haematol 186: 561-564, 2019.

47) Gisslinger H, Klade C, Georgiev P, et al.: Ropeginterferon alfa-2b versus standard therapy for polycythaemia vera (PROUD-PV and CONTINUATION-PV): A randomised, non-inferiority, phase 3 trial and its extension study. Lancet Haematol 7: e196-e208, 2020.

48) Venugopal S, Mascarenhas J: Novel therapeutics in myeloproliferative neoplasms. J Hematol Oncol 13: 162, 2020 